\title{
INSECURITY AND NIGERIA'S SOCIO-ECONOMIC DEVELOPMENT: A SURVEY
}

\author{
WOJUADE James Idowu \\ DEPARTMENT OF SOCIAL STUDIES \\ SCHOOL OF SECONDARY EDUCATION (ARTS AND SOCIAL SCIENCE \\ PROGRAMMES) \\ EMMANUEL ALAYANDE COLLEGE OF EDUCATION, OYO, OYO STATE, \\ NIGERIA, WEST AFRICA \\ E-MAIL: jameswoju@yahoo.com \\ Mobile No: +2348023469676
}

\begin{abstract}
This study examined insecurity as the bane of Nigeria's socio-economic development. The study adopted a descriptive survey research. The study was guided by two research questions. The participants for this study comprised one hundred and fifty (150) educated people/youth selected from Ona-Ara local government area of Ibadan metropolis. Insecurity as the bane of socio-economic development in Nigeria questionnaire was the instrument used for this study. Data collected were analysed using descriptive statistics such as frequency counts and percentage. Findings revealed that ethno-religious conflicts and unemployment are among the factors responsible for insecurity in Nigeria. Social dislocation, population displacement, disruption of family and communal life are some of the impacts of insecurity on Nigeria's socio-economic development. It is recommended that government should ensure that social security programme is pursued and systematically implemented to ensure that the populace meets their basic needs.
\end{abstract}

Keywords: Insecurity, Socio-economic development. 


\section{Introduction}

Nigeria is the most populous country in Africa. Has been tangled in a firebox of insecurity leading to scores of deaths of some innocent civilians, foreigners (investors, students, immigrants and expatriates) also some members of the nation's security personnel, elected officials and many government workers. Some typical examples are ritual killings, suicide bombings, religious killings (like Kano riot of 1994), politically - motivated killing, ethnic clashes (like Fulani herdsmen), Boko haram insurgent, armed banditry and others have become order of the day in our beloved country called Nigeria (Ucha, 2010).

The insecurity challenges have assumed formidable dimension forcing the country's political and economic managers and indeed the entire nation, to regret the loss of their loves ones, investments and absence of safety in most parts of the country (Imhonopi \& Urim, 2012). It is axiomatic to say that there is hardly a country without one security threat or another, just as it is hard to find a state that can completely eradicate all threats to her security (Ukpabi, 1986). Nevertheless, a proper threat perception and analysis allows a country manages her threats properly by allocating resources to the needed area. Imobighe (Alabi, 1997) defines threat as "anything that can undermine the security of the nation, or anything that constitutes danger to her survival as a corporate entity, as well as undermine the prospects of the harmonious relationship of the various communities that make up the nation, or the peaceful co-existence of her people".

Socio economic development is the primary goal of every well-meaning government, and it is essentially dependent on the level of economic activities in a country; the level of economic activities is in turn enhanced by peaceful co-existence by people. In the absence of security, socio-economic development cannot be sustained as it destroys economic, human and social capital. The Boko Haram insurgence in Northern Nigeria has almost crippled economic activities in that region. Also activities of other militia groups in other parts of the country pose serious threat to the economic health of these regions. The security crises in different parts of Nigeria is destroying existing infrastructure and preventing a peaceful environment for the development of further infrastructure and a safe environment for economic activities by individuals to give them economic empowerment that will enable households not only to cater for their present generations, create wealth, but also to provide for future generations.

The bane of Nigeria's development in insecurity. Insecurity situation is costing Nigeria its leadership role in Africa in terms of development. Consequently, more proactive initiatives regarding tackling menace of insecurity are needed in Nigeria since security is central to development, and the national transformation agenda of the current administration may not be achieved if there is no solution to the menace of insecurity ravaging the country.

With this background, this paper therefore seeks to examine the pertinent issue of nation's insecurity a crisis of the Nigerian state, and its implication for Nigeria's socioeconomic development.

\section{Statement of the Problem}

The alarming level of insecurity in Nigeria has fueled the crime rate and terrorists attacks in different parts of the country, leaving unpalatable consequences for the nation's economy and her growth. To address the threat to national security and combat the increasing waves of crime the federal government in the 2018 budget made a huge allocation to security, 
and the national assembly passed the Anti-terrorism Act in 2011. Despite these efforts, the level of insecurity in the country is still high, and a confirmation of this is the low ranking of Nigeria in the Global Peace Index. With the security challenges, the Nigerian government in recent time need to request for foreign assistance from western countries of the world such as the United States of America (USA), Israel, European Union to combat the rising waves of terrorism and insecurity since security measures taken so far have not produced the desired positive result.

With the deteriorating security situation in the country, Nigeria is also confronted with discouraging developmental challenges which pose serious threat to socio-economic development. These developmental challenges include endemic rural and urban poverty, high rate of unemployment, debilitating youth unemployment, low industrial output, unstable and deteriorating exchange rate, high inflation rate, inadequate physical and socio infrastructure, very large domestic debt, and rising stock of external debt.

\section{Research Questions}

The following research questions guided this study:

1. What are the factors responsible for insecurity in Nigeria?

2. What are the impacts of insecurity on socio-economic development in Nigeria?

\section{Conceptual Analysis}

To ably define insecurity, it is pertinent to have a brief discussion on what security is? What constitutes security in modern times is a question that has never been answered satisfactorily by scholars. Its perception even within one community varies in time (Ejogba, 2006). For instance, until recently, most of the mainstream writings on security studies literally defined it in terms of a state's capabilities to defend its territorial integrity from threats, actual and imagined, as well as act of aggression from other potential enemies (Okwori, 1995). For Nwolise (2006), security is an all-encompassing condition which suggests that a territory must be secured by a network of armed forces; that the sovereignty of the state must be guaranteed by a democratic and patriotic government, which in turn must be protected by the military, police and the people themselves.

Conversely, insecurity is the antithesis of security and has attracted such common descriptors as want of safety, danger, hazard, uncertainty, want of confidence, state of doubt, inadequately guarded or protected, instability, trouble, lack of protection and being unsafe and others (Achumba, Ighomereho \& Akpor-Robaro, 2013). For Beland (2005), insecurity is "the state of fear or anxiety stemming from a concrete or alleged lack of protection". It refers to lack of inadequate freedom from danger. In this paper, insecurity is conceived as a situation where human and national security of a state is compromised by internal or external forces or interests exacerbated by the former's weak or poor economic, military and/or human resources development conditions.

Socio-economic development is a product of development and can be defined as the process of social and economic transformation in a society. Socio-economic development embraces changes taunting in the social sphere mostly of an economic nature. Thus, socioeconomic development is made up of processes caused by exogenous and endogenous factors which determine the course and direction of the development. Socio-economic development is measured with indicators such as GDP, life expectancy, literacy and levels of employment. 
Changes in less-tangible factors are also considered such as personal dignity, freedom of association, personal safety and freedom from fear of physical harm, and the extent of participation in civil society.

\section{Causes of Insecurity in Nigeria}

\section{Absence of Institutional Capacity Resulting in Government Failure}

Fukuyama (2004) calls this the breakdown of institutional infrastructures. The foundations of institutional framework in Nigeria are very shaky and have provoked a deterioration of state governance and democratic accountability, thus, paralyzing the existing formal and legitimate rules nested in the hierarchy of social order (Achumba, et al. 2013). This view is collaborated by Igbuzor (2011) who sees the state of insecurity in Nigeria as a function of government failure. This manifests in the incapacity of government to deliver public goods to its citizens. This lack of basic necessities by the Nigerian people has created a growing army of frustrated people who resort to violence at the slightest provocation or opportunity. Although, Nigeria has the resources to provide for the needs of its people, the entrenched culture of corruption in public service has resulted in the dearth of basic necessities, leading to what Hazen \& Horner (2007) call a "Paradox of Plenty". Because of this situation, the crime rate shoots up and the security of lives and property are no longer guaranteed.

\section{The Gaping Chasm of Inequality and Absence of Fairness and Justice}

The perception of marginalization by many Nigerians is informed by the ostentation showed by the political class and elite vis-à-vis the grinding poverty to which citizens are subjected. Even security has been bourgeoisified by the elite. As Egwu (2000) contends, the security of the Nigerian nation-state has been reduced to that of the ruler and his immediate supporters, thus, the security calculus of the Nigerian state has failed because it does not include vital aspects of social and national development supported by the provision of basic social, economic or even military conditions necessary for effective national security. This state of inequality, unfairness and injustice has toughened the people, forcing them to take their destiny into their hands.

\section{Ethno-Religious Conflicts}

Ethno-religious conflicts have been identified as a major source of insecurity in Nigeria (Ibrahim \& Igbuzor, 2002; Hazen \& Horner, 2007; Salawu, 2010; Igbuzor, 2011). Ethno-religious conflicts exist when the social relations between members of one ethnic or religious group and another of such group in a multi-ethnic and multi-religious society is characterized by lack of cordiality, mutual suspicion and fear, and a tendency towards violent confrontations to settle grievances. These conflicts have also revolved around who gets what and how in the state especially as it concerns the distribution of scarce resources, power, land, chieftaincy titles, local government councils, control of markets and expansion of religious territories. These conflicts have resulted in large-scale killings and violence among ethnoreligious groups in the country (Adagba, et al. 2012).

\section{Disconnect between the People and Government}

Over the years, there has been a growing disconnect between the people and government. Governments, whether military or civilian, have not tried to bridge this chasm, 
thus creating misunderstanding, mistrust and resentment. Consequently, because the people do not understand government or have a perception that government does not care about their welfare, they become easy prey to centrifugal forces who co-opt/incite them to vent their anger on perceived enemies of the people and sometimes go to the extent of destroying national totems.

5. Politically Based Violence: Nigeria has a long history of politically based violence since the collapse of the first republic on January 14, 1966, and the incursion of the military into governance that same date. The electoral politics in Nigeria right from 1960s till date have been characterized with violent conflicts, political thuggery, assassinations, and arson. Politicians in Nigerian do not accommodate dialogue, negotiation and consensus (Eme and Onyishi, 2011). Political contests are characterized by desperation, and violent struggle for political power among politicians. Recurring political violence in Nigeria could be attributed to over-zealousness and desperation of political gladiators to win elections or remain in office at all cost. These misadventures have often been catastrophic leading to decimation of innocent lives, disruption of economic activities, and the destruction of properties among others.

6. Unemployment/Poverty: According to Adagba et al. (2012), unemployment/ poverty among Nigerians, especially the youths is a major cause of insecurity and violent crimes in Nigeria. In particular youth's unemployment has contributed to the rising cases of violent conflict in Nigeria. Also, one of the major causes of insecurity in the country is the failure of successive administration to address challenges of poverty, unemployment and inequitable distribution of wealth among ethnic nationalities.

7. Organized Violent Groups: Organized violent groups such as ethnic militia, vigilantes, secret cults in tertiary institutions and political thugs contribute significantly to security challenges in Nigeria in different dimension and forms. Their emergence have been linked to a number of factors which include the culture of militarism that has its antecedents in military rule, the failure of the state and its institutions, economic disempowerment, the structure of the state and Nigeria's federalism, non-separation of state and religion, politics of exclusion, culture of patriarchy, ignorance and poor political consciousness (Ibrahim and Igbuzor, 2002 as cited in Eme and Onyishi, 2011).

8. Weak Security System: This is a major contributory factor to the level of insecurity in Nigeria, and this can be attributed to a number of factors which include inadequate funding of the police and other security agencies, lack of modern equipment both in weaponry and training, poor welfare of security personnel, and inadequate personnel (Achumba et al 2013). According to Olonisakin (2008), the police-population ratio in Nigeria is 1:450 which falls below the standard set by the United Nations. The implication of this is that Nigeria is grossly under policed and this partly explains the inability of the Nigerian Police Force to effectively combat crimes and criminality in the country.

9. Terrorism: The most fundamental source of insecurity in Nigeria today is terrorism which is traceable to religious fanaticism and intolerance particularly in Islam dominated states of Nigeria (Achumba et al. 2013). Terrorism is a global phenomenon and it is ravaging the whole world. It has been defined by Sampson and Onuoha (2011) as "the premeditated use or threat of use of violence by an individual or group to cause fear, destruction or death, especially against unarmed targets, property or infrastructure in a state, intended to compel 
those in authority to respond to the demands and expectations of the individual or group behind such violent acts'.

Terrorism in Nigeria is not a recent phenomenon, it started with the notorious Islamic sect in the Northern part of Nigeria called Mataisine during Alhaji Shehu Shagari civilian regime of the second republic which was aborted by a military coup in December 1983 led by General Muhammadu Buhari. Terrorism rears its ugly head again during the Obasanjo civilian regime of the fourth republic which witnessed religious riots in Plateau State in Northern Nigeria. In recent times terrorism has assumed a political undertone and is been spearheaded by a faceless Islamic insurgents based in the Northern region of Nigeria called Boko Haram, that has claimed thousands of lives in the North since 2009.

\section{Loss of Socio-Cultural and Communal Value System}

The collapse of moral values within Nigeria is one critical factor to the continued security challenges that the country is faced with. The disintegration of communal value system which placed high premium on human life and despised greed, oppression and exploitation of the weak, among others, has also contributed to the unpleasant security environment in the country. New values that are zero-sum, paternalistic, narcissistic, chauvinistic and corrupt in nature and that preach that might-is-right have all taken over. Endearing social values and morals have been traded off for western values.

\section{Immediate and Proximate Factors}

According to Achumba et al. (2013), the proximate factors that have contributed to the state of insecurity in the country are porous borders, rural-urban drift, social irresponsibility of companies resulting in negative externalities which provoke social unrest within their host communities, unemployment and poverty and terrorism, among others.

All these factors combined to create the sultry security situation in the country.

\section{Methodology}

The study adopted a descriptive survey design. The participants for this study consisted of one hundred and fifty people, 80 males and 70 females randomly selected from Ona-Ara local government area of Ibadan metropolis. A ten (10) item questionnaire designed by the researcher titled insecurity as the bane of socio-economic development in Nigeria was used to collect data for this study. It was divided into two sections. Section A dealt with biodata of the respondents. Section B consisted of items related to insecurity in Nigeria. The questionnaire was raised in four scale likert type structure namely Strongly Agree (SA), Agree (A), Disagree (D) and Strongly Disagree (SD). The instrument was validated by two experts from Department of Social Studies, Emmanuel Alayande College of Education. The Cronbach Alpha method was used to calculate the reliability coefficient which was 0.84 . The instruments were personally administered by the researcher. The descriptive statistics of frequency counts and percentage were used to answer the research questions. 


\section{Results and Discussion}

Research Question One: What are the factors responsible for insecurity in Nigeria?

Table 1: Analysis of Factors Responsible for Insecurity in Nigeria.

\begin{tabular}{|l|l|c|c|}
\hline S/N & Items & $\begin{array}{c}\text { Positive } \\
\text { Response (\%) }\end{array}$ & $\begin{array}{c}\text { Negative } \\
\text { Response (\%) }\end{array}$ \\
\hline 1. & Rising cases of youth unemployment and poverty & 89 & 61 \\
\hline 2. & $\begin{array}{l}\text { Weak security system such as inadequate funding } \\
\text { of security agencies modern equipment in } \\
\text { weaponry and training }\end{array}$ & $\begin{array}{c}92.33 \\
40.67\end{array}$ & 58 \\
\hline 3. & $\begin{array}{l}\text { Poor state of inequality and absence of fairness } \\
\text { and justice }\end{array}$ & 114 & 38.67 \\
\hline 4. & $\begin{array}{l}\text { The growing disconnect between the people and } \\
\text { the government }\end{array}$ & 10.00 & 36 \\
\hline 5. & Weak foundations of institutional framework. & 12.00 & 24.00 \\
\hline
\end{tabular}

From table 1, items $1-5$ had $59.33 \% ; 61.33 \% ; 76.00 \% ; 72.00 \%, 82.00 \%$ and $40.67 \%$; $38.67 \% ; 24.00 \% ; 28.00 \% ; 18.00 \%$, positive and negative responses respectively. This implies that rising cases of unemployment, weak security system, poor state of inequality are some of the factors responsible in Nigeria. This result is in line with the views of Egwu (2000) who reported that security of the Nigerian nation-state has been reduced to that of the ruler and his immediate supporters.

Research Question Two: What are the impacts of insecurity on socio-economic development in Nigeria?

Table 2: Analysis of the impacts of insecurity on Nigeria's socio-economic development

\begin{tabular}{|c|c|c|c|}
\hline $\mathbf{S} / \mathbf{N}$ & Items & $\begin{array}{c}\text { Positive } \\
\text { Response }(\%)\end{array}$ & $\begin{array}{c}\text { Negative } \\
\text { Response }(\%)\end{array}$ \\
\hline 1. & $\begin{array}{l}\text { Insecurity makes economy unattractive to foreign } \\
\text { investors }\end{array}$ & $\begin{array}{c}115 \\
76.67\end{array}$ & $\begin{array}{c}35 \\
23.33\end{array}$ \\
\hline 2. & $\begin{array}{l}\text { Insecurity leads to disruption of businesses and } \\
\text { economic activities, retardation of economic } \\
\text { growth and development. }\end{array}$ & $\begin{array}{c}94 \\
62.67\end{array}$ & $\begin{array}{c}56 \\
37.33\end{array}$ \\
\hline 3. & $\begin{array}{l}\text { Insecurity results to social dislocation, population } \\
\text { displacement, disruption of family and } \\
\text { community life }\end{array}$ & $\begin{array}{c}138 \\
92.00\end{array}$ & $\begin{array}{c}12 \\
08.00\end{array}$ \\
\hline 4. & $\begin{array}{l}\text { Insecurity causes mistrust, fear and anxiety } \\
\text { among people }\end{array}$ & $\begin{array}{c}126 \\
84.00\end{array}$ & $\begin{array}{c}24 \\
16.00\end{array}$ \\
\hline 5. & $\begin{array}{l}\text { Insecurity leads to ethnic resentment and } \\
\text { disaffection resulting to clashes and destruction } \\
\text { of lives and properties }\end{array}$ & $\begin{array}{c}143 \\
95.33\end{array}$ & $\begin{array}{c}07 \\
04.67\end{array}$ \\
\hline
\end{tabular}


From table 2, items $1-5$ had $76.67 \% ; 62.67 \% ; 92.00 \% ; 84.00 \%, 95.33 \%$ and $23.33 \%$; $37.33 \% ; 08.00 \% ; 16.00 \%$; $04.67 \%$, positive and negative responses respectively. This indicates that disruption of businesses, social dislocation, destruction of lives and properties are some of the impacts of insecurity on Nigeria's socio-economic development. This result supports the views of Imhonopi and Urim (2012) who reported that insecurity challenges have assumed formidable dimension forcing the country's political and economic managers and indeed the entire nation to regret the loss of their loved ones, investments and absence of safety in most parts of the country.

\section{Impacts of Insecurity on Socio-Economic Development in Nigeria}

After sixty years of nationhood, Nigeria still ranks among the poorest countries in the world, also ranks low in all socio economic indicators such as life expectancy, death rate, access to water, poverty rate, mortality rate, and crime rate, and still carries the tag of a developing economy. Nigeria is a classic illustration of an oxymoron, a poor country in the midst of abundant human and natural resources. This scenario has contributed to security challenges that have bedeviled the country since independence till now with grave consequences for socio-economic development. There is no nation that can achieve socioeconomic development in an environment of socio and physical insecurity. The increasing challenge of insecurity in Nigeria has also been linked to failure of leadership to deliver good governance, and secure the welfare of persons on the principles of freedom, equality, and justice. The ruling elites in Nigeria in both the military and democratic dispensation are dependent, parasitic, and very corrupt in nature, and mal-administration (Ali, 2013).

The inability of government to provide a secure and safe environment for lives, properties and the conduct of business and economic activities has led to resentment and disaffection among ethnic groups. This has resulted in ethnic violence, communal clashes, and religious violence in different parts of the country that has destroyed lives and properties, disrupted businesses and economic activities, and retarded economic growth and development of Nigeria. There is no investor whether local or foreign that will be motivated to invest in an unsafe and insecure environment. In a globalized world, investors are not only looking for high returns on their investments but also safe haven for their investments. Thus, the alarming level of insecurity in Nigeria has made the economy unattractive to foreign investors, and this has impacted negatively on economic growth and development.

Insecurity in Nigeria has retarded socio-economic development in Nigeria in various ways. These include: Social dislocation and population displacement; Social tensions and new pattern of settlements which encourages Muslims/ Christians or members of an ethnic group moving to Muslim/Christian dominated enclaves; Heightens citizenship question which encourages hostility between "indigenes" and "settlers"; Dislocation and disruption of family and communal life; General atmosphere of mistrust, fear, anxiety and frenzy; Dehumanization of women, children, and men especially in areas where rape, child abuse and neglect are used as instruments of war; Deepening of hunger and poverty in the polity; Discourages local and foreign investment as it makes investment unattractive to business people; Halts business operations during period of violence and outright closure of many enterprises in the areas or zones where incidence of insecurity is rife and are on daily occurrence; Increases security spending by business organizations and governments; Migration of people from area or region where there is prevalence of insecurity.

\section{Conclusion and Recommendations}


The real panacea for solving insecurity challenge in Nigeria is for government to accelerate the pace of development. Development in this context consists of creating an economy with relevant social, economic and physical infrastructure for business operations and industrial growth. This will provide gainful employment, high level of educational facilities, and medical care for the people. The result of this would be a very high reduction in the rate of youth restiveness and other social vices that makes criminal activities and tendencies to rise in the society.

Governments at all levels should ensure that rising poverty indices are reversed and a realistic social security programme is pursued and systematically implemented to ensure that the populace meets their basic needs. 


\section{REFERENCES}

Achumba, I.C., Ighomereho, O.S. \& Akpor-Robaro, M.O. (2013). "Security challenges in Nigeria and the implications for Business activities and sustainable development". Journal of Economics and Sustainable Development, vol. 4, No. 2, pp. 77-99.

Adagba, O., Ugwu, S.C. \& Eme, O.I. (2012). Activities of Boko Haram and Insecurity Question in Nigeria, Arabian Journal of Business and Management Review. vol. 1, No. 9, 77-99.

Ali, A.D. (2013). Security and economic development in Nigeria since 1960. Kuwait Chapter of Arabian Journal of Business and Management Review, 2(6), 1-7.

Alibi, D.O. (1997). Issues and problems in the Nigeria defense policy in the 1990s: A critical review. Nigeria Army Journal. 9(3), 128-143.

Beland, D. (2005). The political construction of collective insecurity: From moral panic to Blame avoidance and organized irresponsibility. Center for European Studies Working Paper Series. 126.

Egwu, S.G. (2011). Ethnic and religious violence in Nigeria. Jos: Stephen Book House.

Ejogba, D.A. (2006). African security in the twenty-first century, Nigerian Forum: A Journal of Opinion on World Affairs, Nigeria Institute of International Affairs. 27, (9-10), 303-319.

Hazen, J.M. \& Horner, J. (2007). Small arms, armed violence and insecurity in Nigeria: The Niger Delta in Perspective, Switzerland: Small Arms Survey.

Ibrahim J. \& Igbuzor, O. (2002). "Memorandum submitted to the Presidential Committee on National Security in Nigeria.

Igbuzor, O. (2011). Peace and security education: A critical factor for sustainable peace and national development. International Journal of Peace and Development Studies. Vol. 2(1), 1-7 January.

Nwolise, O.B.C. (2006). "National Security and Sustainable Democracy" in Ojo, E.O. (ed). Challenges of Sustainable Democracy in Nigeria: Ibadan: John Archer Publisher.

Okwori, A.S. (1995). Security and deterrence: Towards alternative deterrence strategy for Nigeria in the $21^{\text {st }}$ century and beyond. Defence Studies: Journal of the Nigeria Defence Academy. Kaduna, 5, 19-28.

Olonisakin, F. (2008). "In the line of Fire". BBC Focus on Africa (April-June) pp. 19-23.

Salawu, B. (2010). Ethno-religious conflicts in Nigeria: Causal Analysis and proposals for new management strategies, European Journal of Social Sciences, volume 13, Number 3, 345-353.

Sampson, J.I. \& Onuoha, F.C. (2011). "Forcing the Horse to Drink or making it realize its thirst"? Understanding the Enactment of Anti-Terrorism legislation (ATL) in Nigeria Perspectives on Terrorism, 5(3-4).

Ucha, C. (2010). Poverty in Nigeria: Some dimensions and contributing factors. Global Majority E-Journal, 1, (1), 46056.

Ukpabi, S.C. (1986). Strands in Nigerian military history Zaria. Gaskiya Corporation. 
Journal DOI: www.doi.org/10.46654/IJRESD

Article DOI: www.doi.org/10.46654/IJRESD.1121

Urim, U.M. (2012). The politics of party formation in Nigeria fourth republic. An Unpublished B.Sc. Project Submitted to the Department of Political Science, Lagos State University, Ojo, Lagos State. 